\title{
AMBIGUITY IN AUTOBIGRAPHICAL NARRATIVES IN NIGERIA: VALORIZING SEXISM AND DISPLACEMENT IN OGONI COSMOLOGY
}

\author{
Christopher Babatunde Ogunyemi \\ Department of English Studies, Adekunle Ajasin University, Nigeria \\ E-mail: bbcoguns2@yahoo.se
}

\begin{abstract}
APA Citation: Ogunyemi, C. B. (2016). Ambiguity in autobiographical narratives in Nigeria: Valorizing sexism and displacement in Ogoni Cosmology. English Review: Journal of English Education, 5(1), 11-24
\end{abstract}

\begin{abstract}
This paper focuses on the examination of ambiguity in autobiographical writings in Nigeria. It underscores the architectonic discourse, cultural alienation and 'self-elevation' in some selected autobiographies. Ambiguity in this instance visualizes that these male narratives hinge on something, which is what we now wish to excavate as an area of serious academic endeavour. And it also hinges on how Saro Wiwa's autobiographies who happen to be male is inevitably sexist in orientation, this will, however, be shown when examining in particular the structuring (narratological devices) of the texts. This work valorizes the cardinal representations of self and male gender in enhancing identity for people of diverse perspectives without appreciating female voices which constitute an integral part of the literary history and ideologue. 'Negating women in art is negating history because history is the main discipline through which we can understand gender' (Brereton, 1998, p. 17). This paper encapsulates the motif of dominance and oppression of women because women were only made to be seen and not heard or even represented in such art. However, this situation is disheartening because while the 'African feminist accommodates men and make them its central assurance, love and care' (Chukwuma, 1990, p. 15), men who are fickle minded literary ideologues delight in over projecting self using the instrument of ' $\mathrm{I}$ ' in autobiographies without recourse to women who hold some basis to their existence. This research work entails a close analysis of the question of gender and displacement originating from these autobiographical writings originating from Nigeria and the configuration of the motif of metaphor in male dominated gender in five autobiographical writings in line with narratology and Butler's Theory of performativity.

Keywords: autobiography, ambiguity, narratives, saro wiwa, butler, narratology
\end{abstract}

\section{INTRODUCTION}

Autobiographical writings are total representations of events surrounding the writer: male or female. Many works have been subjected to the culture of imperialism which in the end shows alienation, pain, sorrow, repression and negation. (Calvino, 2004, Carruth, 1998 and Butler, 1968). However, despite the range and abundance of autobiographical writings from
Anglophone Nigeria, this work fully 'charts the intersection of multiple, contradictory views of the colonial and post colonial images. It illuminates the concept of community and levels of social integration-a persistent pattern of both resistance and accommodation of the domain of male gender in art' (Brereton, 1998, p. 18). Autobiographical works sometimes reflect the entire range of practice, including the slave narrative 
and testimonial, written and oral narratives, spiritual autobiographic, fiction, serial autobiography, verse, diaries and journals, elegy, and parody (D'more, 2012, Folkenflik, 1993 and Raditlhalo, 2003). The intention of this work is to demonstrate how Saro Wiwa uses some selected autobiographical works to show specific levels of degradation and environmental waste which affected Ogoni culturally, economically and politically.

The concern of this work is predicated on the configuration of metaphor in male autobiographical narratives of Saro Wiwa. The use of 'male metaphor', such as artificial creations and self created myths involving the use of ' $\mathrm{I}$ ', and ' $m e^{\prime}$ ' to express life situations most times constitute the focal point for this analysis. In Nigeria, many writers such as Chinua Achebe, Aguda, Soyinka, Obasanjo, Buchi Emechetta, Akachi Ezeigbo among others have typified their works in different dimensions to delineate a cordial relationship with societal superstructure. For Soyinka in Ake, the metaphoric portrayal of self is to denote referentiality between the art and human society; the essence of this is to portray a depiction of art in reality and a reflection of youthful life in contemporary times. Reflecting on an event in Soyinka's narrative he opines that:

$\{T\} r u e$, I had done less of grasscutting than most in the formative years but this had been due to the unlucky accident which had nearly taken off my right eye. It had left a permanent scar, a visible reminder to every teacher of what, to everyone, what nothing short of a miracle. Overawed by this singular mark of divine protection and, reluctant to tempt fate all over again, the teachers simply ordered me back into the classroom whenever it was time for mowing the grass. I had therefore a retarded education in the art of the oju agba but, I did catch up in my last year in the primary school when the incident had become all but forgotten (1981, p. 169).

In the above quotation, the narrator's childhood reflection is a depiction of the nature of memory and creative imagination which portray metaphors that stimulate the social functioning in society. The narrator would have lost his eyes at childhood; incidentally, it is that same eyes that give him the functioning sight of the society he lives in. The same metaphoric element is visualised by Aguda when he says that 'I never planned to go into the legal profession. I had no ambition, hope or desire to do so, until March 1947, when fate seemed to have left me to no other alternative' (1980, p. 1). Fate had left him in a good choice that spurs him to the legal limelight. Writers of the autobiographical narratives either use metaphors in the domain of general and the particular in order to demonstrate their perception of society.

Our intention in this paper is not to be bogged down by the tradition in writing autobiographical narratives but to examine succinctly male dominance and the background of 'patrilineage' in Wiwa's aforementioned works which explain what most Africa society's experience in their contact with one another. According to Nwachukwu Agbada, the ' $\mathrm{I}$ ' in African literary autobiographies refers both to personal and public, the private and civic (1987, p. 10). 'The eye of the society is mostly celebrated in autobiographical narratives' (Nwachukwu-Agbada, 2003, p. 9). Looking at various narratives, one would agree with Emma Kafalenos that 
narrative writings ' provide tools that help to explain the process of perceiving and interpreting event' (2001, p. 36). However, Raditlhalo's 'authorizing the self' is axiomatic, he opines that:

At the heart of life-writing are individuals who begin to narrativise their story in most instances for public consumption. While there may be many reasons why people write their life-narratives, in western society at least the genesis of the genre is usually associated with the Confessions of Saint Augustine (c.400) though it reaches back to antiquity with, say, Seneca's Letters from a Stoic (ca. 63-65). This perception, amongst others, has been instrumental in the logocentricism at the heart of western culture, which is to say that the self has teleological beginning that is uniquely western in origin. It must be added that it is not only western society which has preserved a distinct genre in life writings, as Felicity A. Nussbaum attests $(1988$, n. 8). Despite evidence to the contrary from scholars outside Europe, however, this logocentric view is deeply embedded in western scholarship; an attack on such logocentricism is provided, among other scholars, by Gayatri Spivak (40).

'The concept of 'self' becomes the major preoccupation in autobiographical writings' (Freedom 2004, Raditlhalo, 2003 and Fox-Genove, 1986). While this kind of narration is a representation of sequential events in the narrative. The representation is a process in which events are revealed successively, one after the other. Autobiographical narratives follow the sequence of perceived representation of events conceived in a parallel sequence.

Kafalenos further explains that this kind of narrative is a sequence in which the identical events occur in chronological order. The Russian formalist named the two sequences: Sjuzhet (the representation) and Fabula (the chronological sequence abstracted from the representation). Fabula is made by readers from the information found in a Sjuzhet. Nigerian autobiographical writings also conform to the application of both Sjuzhet and Fabula in their narrative portrayal of self in society. The readers make their comments from the explications found in the documented texts and thematic preoccupations which are deeply rooted in the autobiographical narratives. The essence is to guide readers to discern a particular metaphoric configuration in relation to literary activities which interpret given events. Readers are led to include in a configuration certain revealed events and not others primarily by the relation between a Sjuzhet and its Fabula-a relation that is illuminated by gaps (Kafalenos, 2001, p. 32). According to Kafalenos in looking at Barthes'

'Autobiography', he opines that: $\{$ R\}oland Barthes identifies "narrative contract" which throws some searchlight in the importance of autobiographical narratives. The bargain in this instance is between the narrator (of both the framing narrative and the contained narrative). As we begin to read the autobiographical narrative, on the first reading, we discover initially Mine de Rochefide's motivation. The narrator's companion is fascinated by the painting she sees at the party to which the narrator has taken her and she says she is "too beautiful for a man" (Honore de Balzac). The narrative form of an autographical writing is usually shared by both historiography and fictional narrative. This is considered to be the most important parallel between the two genres. Here, contemporary literary and historical theories view 
historiography as another art form, which predominated until mid-19 $9^{\text {th }}$ century (Ibid).

Contemporary writers like Hayden White (1978) have also attempted to prove the fictional character of historiography by examining its narrative structures and recourse to literary modes of narration. White focuses on the narrative structures at the surface of the texts; he determines the instruments that constitute narrative force (ibid). Nigerian autobiographers get their raw materials from historical issues; this is what White in the words of Aristotle tags 'mimetic representation' of real historical occurrence or historical processes which are part of the narratives. In addition, they are contingent, metaphorical and, in the final analysis, fictional constructs. This means that historical discourse should not be considered as mirror image of the set of events which we simply describe autobiographical (ibid). Writings attempt to prove that language and narrative form are not transparent media that merely enable the neutral representation of historical processes. Chukwuma remarks that the woman is portrayed in various works including the autobiographical narrative as 'a handicapped daughter, wife and mother even when the decisions affect her directly' (2004, p. 131). Various narrations have portrayed the fact that the most feasible way to $x$-ray gender factor of female subjugation in written autobiographies is her economic dependence on men and the social demand that a woman give all her earnings to the home (132).

Autobiographical literature is as old as man; it spreads gradually from the old period in art till this present dispensation. Autobiographical works take many forms, from intimate writings made during life that are necessarily intended for publication (including letters, diaries, journals, memories and reminiscences to formal autobiography (Freedom, 1993 and Goodman, 1993). 'Outstanding examples of the genre extended from St Augustine's Confessions (c. AD 400) to Vladimir Nabokov's Speak Memory (1951). Autobiographical narratives, as literary genre, narrate the story of one's own life' (Raditlhalo, 2003, Green, 2009 and Hughes, 1993). This writing is predicated on 'the individual's quest to narrate his psychoanalysis; this is of interest as the story is told by the patient to the analyst and to himself' (Nwachukwu-Agbada, 2003, p. 67). In the modern sense, autobiography began as a form of confession (Saint Augustine), even though there are memoirs in classical literature, such introspective works can be considered attempts at self-analysis before the psychoanalysis discovery of the unconscious. In 1925, Sigmund Freud wrote an Autobiographical Study, in which the story of his life merges with that of the creation of psychoanalysis.

According to Freud, biographical truth does not exist, since the author must rely on lies, secrets and hypocrisy. The same is true of autobiography. From this point of view, it is interesting that Freud framed his theoretical victory and the birth of psychoanalysis in the form of a psychological novel.

The function of autobiography is to use scattered bits of memory to create the illusion of a sense of continuity that can hide the anxiety or even of the absence of the meaning of existence, from a purely narcissistic point of view (Smith and Watson, 2010, Smith, 1993 and 1987, Chadwick, 2008). The selfreflection in Nigerian autobiographical narratives intensifies cultural identity, colonialisation, post-independence 
disillusionment, 1967 to 1970 war experience, the military in politics, corruption in governance and selfrepresentation.

The main assumptions of the study are that, if the preoccupation of the male autobiographical narrative is a relative phenomenon to the understanding of historical and socio-cultural configuration in a dynamic society and if the depiction of self in autobiographical narratives is a reflection of developmental current in Nigerian worldview. These are the tentative questions the research work attempts to raise and answer in order to explore the literary implications which Nigerian autobiographies portray. The questions include:

(a) That the configuration of metaphor in male autobiographical narrative propels self-histories in Nigerian literature.

(b) That these narratives explore some literary devices which point to the glorification of men and their achievements by the image of ' $\mathrm{I}$ '.

(c) That in the course of the exploration of these narratives, there are instances of gender conflict which lead to gender consciousness among Nigerian women folks.

(d) And that there is need to identify some lopsidedness in the projection of self in order to enhance distinct political, social and economic harmony among women for total posterity.

The overall aim of the study is to explore succinctly the conceptualization of male metaphors in autobiographical narratives. Generally, this work will, the first, focus on the postcolonial male autobiographies in a multi dimensional perspectives with the exposition of the power instrumentations in order to fully explain the focus behind such writings and why they are male dominant. It would situate practical development where all and sundry regardless of sex can be free to contribute to national development socially, economically, and physically and practically. It could create 'an atmosphere in art whereby such writings have brought about awareness on the part of the women in particular and society in general because with awareness comes education and consciousness-raising, then reaction against all forms of sublimation, denial and marginalization which some forms of writings stand noted for' (Chukwuma, 2004). The second, juxtapose these narratives that originate from Nigeria by explaining the various movements which shape the narrative metaphors, images and the use of male dominated ironies of marginalization in the corpus of the works. The third, succinctly investigate the multiplicity of meanings attributed to these male dominated autobiographical stories and natural archetypes they create to limit the exploration of the female gender in art and literature. This would be done by evaluating the philosophical perspectives which govern the notion of "omnipotence" for Nigeria men in their worldview as visualized in literature. The fourth act as interface of liberation for the colonized and give the male colonizer a new sense of vision and purpose because strength and gender are not integral factors in enhancing practical and sustainable development which make globalization enhance development in Nigeria.

The study which investigates male autobiographical narratives and gender imperatives has these four-fold objectives as specific aims:

(a) It $\mathrm{x}$-rays recurring male features as archetype in Nigerian autobiographical writings. 
(b) It exemplifiers elements of gender distinction and the various reactions attributed to this phenomenon.

(c) It shows related reactions in some related primary sources emanating from Nigeria.

(d) The study visualizes the domination of male configurated metaphors in the autobiographical writings; this factor limits the scope of scholarship society would have been better propelled socially, economically, politically, etc.

Saro Wiwa's A Forest of Flowers (1986) encapsulates ' $I$ ' to metaphorically delineate the hypocrisy of the Nigerian government, the church and fellow Nigerians. In this work, Wiwa presents himself as a portrayal of reality which virtually exposes the various problems encountered by the Nigerian people, particularly the Ogoni people. Similarly, On A Darkling Plain (1989) is one of Wiwa's war diaries which document the Nigerian war experience, this autobiography details levels of political and economic exploitation the Ogoni people suffered in the hands of successive Nigerian governments. It valorises the sad experience people had in the hands of the multi-national companies that came for oil exploration in the area. Genocide in Nigeria (1992) takes a cursory overview of a man's overview and expression of the politics and the environment of the Ogoni environment. In his self-remarks, Wiwa uses his personal experience to denote the plight of the minority and the economic domination of the Ogoni by the Nigerian government. The trend shifts to Sozaboy (1994) which enhances personal perspective of the Ogoni environment. Here, Saro Wiwa demonstrates his personal hatred of the domination of the Nigerian government over the Ogoni resources and the application of brutal force to reduce the Ogoni people through the military encroachment in the area. The work $x$ rays a self- experience of the tragedy meted out to the Ogoni minority in Nigeria. A Month and a Day: A Detention Diary (1995) is an exploratory autobiographical account of Ken Saro Wiwa's period in detention. This work echoes the struggle to liberate the Ogoni people from the shackles of Nigerian imperialism. Eventually, he lost his life to the struggle to liberate his people by the Sanni Abacha self-created judicial enquiry that recommended him for hanging in Port Harcourt in 1995. The choice of these works is to attempt an examination of ambiguities in Saro Wiwa's autobiographical narratives in order to showcase various experiences beginning from the Nigerian/Biafran war time to the total reliance on crude oil by Nigeria and to the total operation of the Nigerian minorities. It explains the suppression of the Ogoni people and subsequently the contemporary times when economic, political failures have eroded some cultural inclinations in Nigeria and the need to expose some levels of corruption and marginalisation of values in the nation's economy. The above stands as the motivation for the above mentioned justification of works.

\section{METHOD}

The treatment of these research answers to so many questions which are yet to be attended to will enhance the understanding of myth, gender in Nigerian autobiographies where the non-existence of female voices in the works of art is feasible. How can equality and sustainable development that is devoid of sexist discrimination be allowed to prevail? A study of unity of purpose in writing would make Nigeria 
take a dynamic and mutual relationship in creative art.

This research work entails a study of 'Ambiguity in Ken Saro Wiwa's Autobiographical Narratives in Nigeria'. For that reason, the work will incorporate the desktop writing with the corpus of its primary sources as mentioned above. It will blend the primary sources with the secondary sources that are retrieved from the library. The content analysis will dovetail into the critical analysis of our chosen texts. Qualitative approach will be applied to delineate the subject matter of the project. A qualitative approach will be expedient because 'it will underscore perceptions around the characters in the literary work of art as they move in time and space' (Okpara1990, p. 115). The methodology embodies a close analysis of trends and prognosis of the concept with recourse to the meta-analysis of both the primary and secondary sources. In analyzing the work, attempts shall be carried out in explaining explicitly the salient points which constitute the subject matter. I will use narratology as instruments to delineate the motif of self and male metaphor in literary analysis to evaluate the themes of gender and development in the Nigerian autobiographical writings. The methodology also entails the application of this theory in the development of the thesis by blending theories with the traditions of writing.

\section{RESULTS AND DISCUSSION}

For proper understanding of this study, narratology as a literary theoretical would be employed to showcase the application of the science of fiction in autobiographical narrative Mieke Bal's Narratology (1985, p. 3) and Gérard Genette (1980) define narratology as the theory and the study of narratives. For the sake of this study, we shall dwell on Gérard Genette narratological works and apply it to the evaluation of our study because the theory aids the German and AngloSaxon literary tradition, and it sheds more light to the understanding of the narratological criticism. However, 'narrative does not represent real or fictive story, it recounts it, that is, it signifies it by means of language. There is no place to imitate the narrative. There are simply varying degree of diegesis, narrative moods, mimesis and every text discloses traces of narration' (pp. 42-43). In addition, narratology lends axiomatic credence to the 'context of production as fundamental element of the narrative' (40).

Narratology details narrative structure and the way it affect our perceptions is examined. In principle, narratology can refer to any systematic study of narratives, though in practice the use of the term is rather more restricted. It is because of this restricted application that this theory is applied to the study and understanding of the male autobiographical narratives and gender imperatives. The word 'narratology' is an anglicization of the French word 'narratologie' Tzvetan Todorov in his Grammaire du Decameron (1969), coins the word, and has been retrospectively applied by many writers. Although a linage stretching back to Aristotle's Poetics may be traced, modern narratology is most typically said to begin with the Russian formalists and in particular with VIadimir Prop's Morphology of the Folktale (1928). Due to the origin of the term, it has a strong association with the structuralist quest for a system of formed description that can usefully be applied to any narrative. This aim has not, however, characterized 
all work that is today described narratological.

$\{$ P \}ercy Lubbock's groundbreaking work on point of view, The Craft of Fiction (1912), is a case in point. Jonathan Culler argues that the many strands of narratology are all united by recognition "that the theory of narrative requires a distinction between: Story" sequence of actions or events, conceived as independent of their manifestation in discourse and 'discourse', the discursive presentation of narration of event" (Labov, 2006, p. 49).

Culler admits that the distinction in narratology is originally proposed by the Russian formalists who used the terms Fabula and Sjuzhet, but a succession of other pairs has perceived what is essentially the same dichotomy for example (christoire/discous historie/recit, story/plot) in his text, The Pursuit of Signs (1981, p. 13). To a certain extent, the designation of work as narratological or otherwise may have more to do with narratives, stories, autobiographies and sociolinguistics. According to Labov (2006), narratology lends credence to conversional analysis, discourse analysis that deal with arising in the course of spontaneous verbal interaction (190). However, constituent narrative structure could be included in the interpretation of male autobiographical narratives (15).

More importantly, narratology enables the readers and critics to examine the structure of the autobiographical writings, their cultural artifacts and the ordering of time and space in narrative forms. This is because narratologists love to categorize and to taxonomize, which has led to a plethora of terms to explain the complicated nature of media in our lives (television, film, fiction). Nwachukwu-Agbada (2003 and 1987) captures the dynamics of autobiographical writing by asserting that these works celebrate ideas, which is spread across periods of time. His conception is predicated on the environment and 'the result is that practically all the Africa literary autobiographies are public gestures derived from a personal struggle with life and agents on the way of psychic, economic, material individual and national fulfillment' (2003, p. 103). A preponderance of issues, which African autobiographical narratives discuss, reveals various exploitations within the domain of narratology. 'Nigerian autobiographies are not exception because they incorporate various issues in their corpus' (1987, p. 97). Essentially, 'gender is a series of displays or performance' (Golfman 1957, p. 22, West, 1988, Zimmerman, 1975, p. 157 and Lucal, 1999, p. 19).

To Henry MacDonald (1988), narratology is traditionally the story of narrative fiction, which is directed mainly to the level of the action of the story and its meanings (1). He further observes that narratology visualizes the narrative presentation of the story which the reader encounters. The story as a separate part of the presentation is an abstract constructed tale. Hawthorne opines that it deals with interpretation and the interpretation is "twice-told all telling ultimately retellings (ibid).

Research in narratology is both prescriptive and descriptive, 'although this may be socially altered' (Epstein, 1988, p. 231).

The analysis is dynamic because autobiographical narrative is a complex phenomenon. The research blends narratological theory with gender theory. The need for the application of these theories is to bring out the Nigerian literary ethos in a manner that 
will explore the configurated metaphors art. Other researchers have used many approaches to examine the narratives in their own ways. Strauss and Corbin (1998) applied the analytic strategic approach in their literary application of art. Luke Eyoh (2003), Raditlhalo (2003) and Chukwuma (1990), use the sociological approach as suitable critical framework, which clearly illuminate the position of characterization and how they become relevant to the contemporary society in autobiographical and critical analysis. The first aim is to identify elements of existing scholarly definitions that support an autobiographical narrative and then relate the approach to narratology.

The significance of this work lies in its extension of previous literature on male autobiographies and gender perceptions. This research work concerns itself with male autobiographical narratives and gender imperatives with concrete allusions to selected autobiographies from Nigeria. Most autobiographical narratives encapsulate self-histories with a continental or national perception. This category of writing could be vividly perceived to qualify as literary material because of the inescapable manner the autobiographical writers weave functionality and artistic brilliance in their works. The significance of the research lends credence on the patterning of gender matrix with recourse to sociological reference. Sociological references here would conceptualise the place of autobiographical narratives in the dynamics of Nigerian landscape. We choose to select male authors because of the peculiar theme of male chauvinism and related sectional metaphors which are embedded in our collective memory. Narratology and autobiographical narratives demonstrate more insight into the application of scientific instruments in African narratives.

Autobiographical works capture many strands of 'events and sequences in human society' Raditlhalo, 2003, Sternberg, 1988 and Spegman, 1980). However, one can say that 'autobiography covers the many different accounts that authors make of their experiences' (Berryman 1999, p. 72 as quoted by Javangwe, 2011, p. 8). 'The term is a derivation from a Greek word 'auto' meaning 'self', 'bios' - 'life' and 'graphe'- writing. In etymological sense, autobiography thus refers to self and life writing' (Ibid). This account goes further to comment that:

Memoirs are included in the scope of autobiography that gives particular attention to matters of contemporary interest not closely affecting the author's inner -life. There are obvious conflations into generally accepted autobiography, as a genre, autobiography cannot exist without either of the elements of fact or fiction (Ibid).

Autobiographical study propels the understanding of the framework of self in the depiction of personal experience, 'the self and national identity' (9). However, autobiographical narrative 'constructs the individual as a distinct existence from the rest and at another allows the same individual to be subsumed within this group as the embodiment of its core values' (10). The autobiographical narrative, therefore, locates

the individual more critically at the centre of nationalistic politics. Autobiography then performs the narrative function of capturing the individual lives that are both congruous and dissonant with the cultural fictions encouraged and imagined through the nation as an 
imagined community (Anderson, 1983 as quoted by Javangwe, 2011, p. 11).

Inherent themes of man and society dominate the preoccupations of autobiographical art. This preoccupation is brought about by language which is used to express the 'representation of series of events' (12). This 'series of events' is regarded as being sequential in autobiographical work because it expresses the narrative by exploring its relevance, significance and purpose. Autobiographical work of art moves in time and space. It examines the chronological and systematic rendition of one's life experience in various dimensions. To start with, Raditlhalo (2003) traces the origin of autobiographical writing to the Confessions of Saint Augustine. His observation is axiomatic of the fact that life writing becomes transmitted from one generation to the other. He further submits that:

Following the tradition of Saint Augustine, for example, coins the autobiography of Jean-Jacques Rousseau (The confessions, 1781), which ushered in the male secular hero intent creating himself with a view to worldly fame and success. As Jill Kerr Conway suggests, this model of the Napoleonic hero emerges next to Augustine and Rousseau in creating the self "who embodies the feelings of his people in battle for political and economic freedom". Later comes economic man as a model, self created, given full expression in Benjamin

Franklin's Autobiography (41).

Though, autobiographical writing emerges within the Western scholarship, it has gained frequency in world literature and, African Literature is not an exception. The major preoccupation in the autobiographical narrative is the portrayal of 'self' which has been portrayed as a vehicle of transmission of cultural values and idiosyncratic nouns of human society. However,

The self-absorption of the male hero in the texts is perhaps unsurprising: after all, History (with a capital " $\mathrm{H}$ ") has always been seen as gender-based, and therefore what western writers wrote was taken as germane. The feeling that an 'authentic' reality can be brought about through the strivings of individuals might account for the reverence in which certain early thirtieth-century writes are held and canonized (42).

Although Raditlhalo models the Sidonic Smith's 'teleological aspects of all purposeful, rationalizing the self' by 'interlocking phrases in western society' (42) to the concept of self in African cosmology while Vambe's From Rhodesia to Zimbabwe (1978) models critically the autobiographical fact and fiction to explore results. My arguments dovetail into the exploration of male metaphors in selected autobiographical works to illuminate the element of gender configuration in Nigeria. These explorations shall visualize the definitions of 'self' in reality because:

This presupposes phrases which reality is mediated by the self, seeking reason for life's inexplicable phenomena and arriving at a logo which makes meaning of one's life patterns. But central to such reasoning, in Heracliatean terms, is an important premise that at each juncture of this continual search the self evolves (Raditlhalo, 2003, p. 44).

'If we therefore consider the self in autobiographical writing, we realize how, even with narratorial progress, the Logos of the self keeps changing, reflecting and refracting its milieu and circumstances' (Ibid). It is these reflections of circumstance that 'refract' 
various male motifs writers of autobiographies attempt to demonstrate in their writings. Male and female dichotomies in autobiographical art are 'resolution of the social impasse within the purview of the Hegelian dialectic of thesis and antithesis in the oppressor/oppressed matrix' (Fanon, 1967). The proposal for such resolution betrays a materialist, dialectic vision stridently amplified by most autobiographical writers.

The major terms explored in this thesis include 'autobiography' 'narrative and gender imperative', I will only limit myself to their connotative definitions here because these terms would subsequently be applied to my future discourse. By so doing, we shall experience their deep and implied meanings as they are used connotatively and denotatively

a. Ambiguity

Uncertainty or inexactness of meaning in language. A lack of decisiveness or commitment resulting from a failure to make a choice between alternatives. (Free Dictionary)

b. Autobiography

A story about a person's life, written by that same person or a self writing. Raditlhalo sheds more light on the scenario:

Autobiographical texts exemplify Eagleton's point because they use fictional narrative strategies. Whereas the account we read is 'true', in its rendition the society's self-representation is reconstructed by the subject who draws on the full range of linguistic flexibility and the permutations of descriptiveness and metonymy that are denied a formal, straight historical account of any era. However, this does not mean that such historical predicates are a basis for what can be outright lies, but rather that it is for the subject the very fabric in which to insert a life. Thus, in order to explicate autobiographical writings of the periods under study, it is essential to bear in mind the intertwining of history with power (or lack thereof), together with culture. While autobiographical subjects, for want of any other yardstick with which to delineate time, will necessarily refer to dates as markers of their passage from one stage to the next in life, these significations of 'real lives' remain but attempts to partially abolish the very history within which they operate. History cannot be left behind, or totally discarded, but autobiographical subjects seek to defy its autonomy in the construction of their identities (2003, p. 61-62).

c. Narratives.

Descriptions of events (either in a diachronic way or in a synchronic way-emphasis mine)

This work would be a contribution to research on male autobiography and the gender question. This issue of gender is of paramount importance to world literature and globalization. Many autobiographical would see the work as a redirection while creating new myths and metaphors in order to satisfy the yearnings of development and globalization, equality and the understanding of class stratifications in new writings. The work is also a recent contribution to academics.

\section{CONCLUSION}

This section probes into the concept of male autobiographical narratives and Gender Imperative in Nigeria. It is 
expedient to state the aforementioned autobiographical narrative follows the sequence of literary ideologue that lends credence to male superiority and female relegation in literature. The study will demonstrate that in any social context, there is bound to be conflict and conflict resolution. Narratology and autobiographical theory were used to explore the basis for this presentation. This analysis is contained in an assertion that autobiographical works 'charts the intersection of multiple, contradictory views of the colonial and post-colonial images. It also examines the concepts of community integration and levels of social integration. It appreciates persistent pattern of resistance and accommodation within the levels of male gender in arts' (10) as it moves in time and space.

\section{REFERNCES}

Bal, M. (1988). Narratology: Introduction to the theory of narratives. U Totonto Press.

Balzac de H. Factual Narratives". Retrieved from http: //en.wikipedia.org/wiki/ Honor\% C3\% A9 de Balzac

Brereton, B. (1998). Gender in contemporary literature. May and Baker. New York.

Berryman, C. (1999). Critical mirrors: Theories of autobiography, in Mosaic: A Journal for the Interdisciplinary Study of Literature.

Butler, L. (1968). The difficult art of autobiography. Oxford: Claredon.

Calvino, I. (2004). Hermit in Paris: Autobiographical writings. New York. Vintage.

Carruth, H. (1988). Reluctantly: Autobiographical essays (writing rewriting) Port Townsend: Copper Canyon Press.

Chadwick, H. (2008). Saint augustine: Confessions. Oxford University Press.

Chukwuma, H. Women writing: Feminism and national development in Nigeria (An Inaugural Lecture Series, 35 University of Port Harcourt, February 5, 2004
Voices and Choices: The Feminist Dilemma in Four African Novels Literature and Black Aesthesis, ed Ernest N. Emenyonu, Ibadan: Heinemann, 1990

Culler, J. (1981) The pursuit of signs: Semiotics, literature, deconstruction. (eds.). Ithaca Cornell UP.

D'more, J. (2012). American authorship and autobiographical narrative: Mailer, Widerman Eggars, (American Literature Readings in the TwentyFirst Century). Basinstoke: Palgrave, Macmillan.

Epstein, C. F. (1988). Deceptive distinction: Sex, gender, and the social order. New Haven: Yale University Press.

Eyoh, L. E. Socio-political protest and poetic imagination in Clark-Bekederemo's poetry. J. English Studies University Port Harcourt, April 2003.

Fanon, F. (1967). The wretched of the earth. Trans. Constance Farrington. Harmondsworth: Penguin.

Folkenflik, R. (1993). Introduction: The institution of autobiography. Robert Folkenflik (eds.). The culture of autobiography: Constructions of selfrepresentation. Stanford: Stanford U. Press.

Fox-Genovese, E. (1986). My statue, my self: Autobiographical writings of AfroAmerican women. Shari Benstock (eds.). The private self: Theory and practice of women's autobiographical writings. London: Routledge.

Freedom, P. D. (2004). Autobiographical writing across disciplines: $A$ reader. Durham: Duke University Press Books.

(1993). The intimate Critique: Autobiographical Literary Criticism. Durham: Duke University Books.

Freud, S. (1925). An autobiographical study, SE 20.

Garfinkel, H. (1967). Studies in ethno methodology. Englewood Cliffs, NJ: Prentice-Hall.

Goffman, E. (1959). The presentation of self in everyday life. New York: Doubleday. 
ENGLISH REVIEW: Journal of English Education Vol. 5, Issue 1, December 2016
ISSN 2301-7554

https://journal.uniku.ac.id/index.php/ERJEE
Goodwin, J. (1993). Autobiography: The self made text. New York: Twayne.

Genette, G. (1980). Narrative discourse. Cornell University Press.

Green, T. T. (2009). A fatherless child: Autobiographical perspectives of African American. Men. LeMone: University of Missouri Press.

Head, B. (1990). A woman alone: Autobiographical writings. London: Heinemann.

Hughes, L. (1993). I wonder: An autobiographical journey. New York: Hill and Wang,

Javangwe, T. D. (2011). Contesting narratives: Constructions of the self and the Nation in Zimbabwean political autobiography. Unpublished D.Litt et Phil Project submitted to the Department of English Studies of the University of South Africa, UNISA.

Kafalenos, E. (2001). Not yet knowing: Epistemological effects of deferred and suppressed information in narratives New York. The Psychology of Life Stories Reviews of General Psychology, 5, pp. 100-122.

Labov, W. (2006). The social stratification of English in New York city. Washington, D.C. Centre for Applied Linguistics, Cambridge: Cambridge University Press.

Lucal, B. (1999). What it means to be gendered me: Life on the boundaries of a dichotomous gender system. Gender and Society 13, pp. 781-797.

McAdams, D. P. (2005). The wisdom of experience: Autobiographical narratives across adulthood. International Journal of Behavioral Development, 29(3).

Mc Adams, D. P. (1990). Unity and purpose in human lives: The emergence of Identity as a life. story. In A.I Rabin, R.A.Zucker, R. A. Emmos, \& R. A. Frank (Eds.). Studying persons and lives (pp. 148-190). New York: Springer.

McDoanld, H. (1988). The narrative act: Wittgenstein and narratology. Oxford: Basil Blackwell.
Nwachukwu-Agbada, J. O. J. (1987). Protect and faith in wole Soyinka's autobiographies. The Literary HalfYearly xxviii. 2.

Nwachukwu-Agbada, J. O. J. Environment and ' $\mathrm{I}$ ' of the beholder in African literary autobiographies. Working Papers. A Journal of English Studies (University of Port Harcount) (Eds.). Eldred Ibibbien Green, April 2003.

Okpara, C. (1990). The foot as metaphor in female dreams: Analysis of zaynab alkalis novels' Literature and Black Aesthestics. (Eds.). Ernest N. Emenyunu, Ibadan: Heinemann.

Prop, V. (1985). Morphology of the folktales. 1928. Wallston. Hillsdade, NJ: Lawrence Erlbaum. Associates, Inc.

Raditlhalo, S. I. (2003). Who am I? The construction of identity in twentiethcentury South African autobiographical writing in English. A PhD Dissertation Submitted and Published by the University of Groningen, The Netherlands.

Saro Wiwa, K. (1986). A Forest of Flowers. London: Longman.

Saro Wiwa, K. (1989). On a darkling plain: An account of the Nigerian civil war. Port Harcourt. Saros International Publishers.

Saro Wiwa, K. (1992). Genocide in Nigeria. Port Harcourt. Saros International Publishers.

Saro Wiwa, K. (1994). Sozaboy. Ibadan: Longman.

Saro Wiwa, K. (1995). A month and a day: A detention dairy. London: Penguin.

Smith, J., Dixon, R. A., \& Baltes, P. B. (2000). Expertise in life planning: A new research approach to investigating wisdom. In J. D. Sinnott, F. A. Richards., \& C. Adams (Eds.). Adult development: Comparisons and applications of developmental models. Vol. 1. New York: Pager.

Smith, S., \& Julia, W. (2010). Reading autobiography: A guide for interpreting life narratives, 2nd Edition St Paul: University of Minnesota press. 
Smith, S. (1993). Subjectivity, identity and the body: Women's autobiographical practises in the twentieth century. Bloomington and Indianapolis: Indiana University Press.

(1987). A poetics of women's autobiography: Marginality and the fictions of self-representation. Bloomington: Indiana University Press.

Spengeman, W. (1980). The forms of autobiography: Episodes in the history of a literary genre. New Haven \& London: Yale University Press.

Sternberg, R. J. (1998). A balance theory of wisdom and autobiographical narratives. Review of General Psychology, 2, pp. 347-365.

Strauss, A., \& Juliet, C. (1998). Basic of qualitative research thousand. Oaks, CA: Sage Publications.
The Free Dictionary. Retrieved from http:/ / www.thefreedictionary.com/m etaphor

Todorov, T. (1969). Grammaire du decameron. The Hague: Montou.

Vambe, L. (1976). From rhodesia to Zimbabwe. London: Heinemann.

Webster, J. D. (2003). An exploratory analysis of a self-assessed life story. Journal of Adul Development, 10, pp. 13-22.

West, C., \& Angela, G. (1988). Conversational shift work: A study to tropical transitions between women and men. Social Problems 35, pp. 55-575.

White, H. (1978). Topics of discourse: Essays in cultural criticism. Baltimore: The John Hopkins.

Zimmerman, D. H., \& Candace, W. (1975). Sex role, Interruptions and silences in Conversation. in Language and Sex: Difference and Dominance, ed. B. Thorne and N. Henley. Rowley, MA:

Newbury House. 